\title{
The Extent of Inadequate Drug Storage: A Household Survey in Jatinegara, East Jakarta
}

\author{
Yusmaniar*, Purnama Fajri, and Nanda Puspita \\ Department of Pharmacy, Politeknik Kesehatan Jakarta II \\ Jakarta, Nigeria \\ ${ }^{*}$ Corresponding author's email : yusmaniarys [AT] gmail.com
}

\begin{abstract}
----
Background: Poor drug storage at home may lead to physicochemical degradation of drugs and in further cases, irrational drug use. This study aims to investigate the tendency of inappropriate storage, the purpose and type of drugs kept at home, as well as predicted risk factors.

Methods: Study involved 295 households as respondents obtained from multistage cluster sampling. Structured questionnaire was utilized to gain the data and logistic regression analyses were employed to estimate the factors association with improper storage.

Results: Out of 295 respondents, 269 (91.2\%) were females, unemployed (228; 77.3\%), aged under 45 years old (162; $54.9 \%)$, and most had only attained secondary level of education or less (273; 92.5\%). Out of 2571 drug items stored, the most common drug was analgesics $(581 ; 22.6 \%)$. Antibiotics account for approximately ten percent item stored at home. Most of drugs kept at home were intended for future use (1265; 49.2\%). There were 82 households kept ethical drugs without prescriptions. The risk of inadequate drug storage was significantly increased with older age (adjusted $O R=0.591,95 \%$ CI 0.342-1.021, $p=0.05$ ) and employment status (adjusted OR=0.418, 95\% CI 0.229-0.760, p=0.004). The average number of drugs kept at home had correlation with chronic disease treatment in the family $(p=0.046)$ and when no children under 5 years of age $(p=0.033)$.

Conclusions: poor home drug storage require further patient education to prevent drug misuse and preserve the good quality of drugs.
\end{abstract}

Keywords---- inadequate drug storage, household survey, quality of drugs, irrational drug use

\section{INTRODUCTION}

Storing drugs at home is a common behavior in community in order to alleviate minor symptoms and treat chronic diseases for family members [1]. Globally, drug storage behavior has been widely studied in various countries both developing and developed countries with varied results. Studies in Belgium reported that most people have stored drugs well in special containers and understand the risks of improper self-medication with ethical drugs, especially antibiotics [2].However, some developing countries showed high storage of prescription drugs and the intention for self-medication with these drugs. $[3,4,5,6]$. Inappropriate drug storage in both the ways and item of drugs being stored may trigger irrational use of the drugs, waste of healthcare resources, and a risk on human health $[6,7]$.

According to the Basic Health Research (Riskesdas) held in Indonesia in 2013, 35.7\% (105,304 / 294,969) of the sample households kept medicines for self-medication. The region with the highest proportion of drug storage was DKI Jakarta $(56.4 \%)$. The survey results also mentioned that there were high storage of ethical drugs purchased without a prescription (the highest proportion in Lampung, 90.5\%) and proportion of antibiotic storage (the highest proportion in Central Kalimantan, 93.4\%) [8]. This showed inappropriate self-medication behavior in the majority of Indonesians.

Study of drug storage has previously been carried out in North Jakarta by focusing on the type of drugs being stored and how to obtain it. The results of the study showed that $82 \%(205 / 250)$ of households stored drugs at home with mostly analgesic drugs \& NSAIDs (76.1\%). Of the total 1001 medicinal products stored, $31.6 \%$ are leftover drugs which contain antibiotics. Among 720 drug products purchased without a prescription, 125 items are ethical drugs [9]. Investigation regarding the suitability of the place and mode of drug storage have not been explained in the study. Therefore, the present study aims for adopting the same health issue in the administrative area of East Jakarta by adding an analysis of the appropriateness of storage methods and factors that might influence the behavior of drug storage at home. 


\section{METHOD}

A cross-sectional study was conducted in the Jatinegara sub-district community, East Jakarta, Indonesia in August 2017. Jatinegara Sub-district has a population of around 270,000 with a total of 90,869 households. The sample was taken in 300 households (margin of error 5\%, confidence level 95\%). The sampling technique was multistage cluster sampling. In the first stage, household as a unit of study were taken from $20 \%$ of the total 8 villages in Jatinegara sub-district, namely in 2 villages. In the second stage, $20 \%$ of the total 24 blocks in the two villages are used as sampling areas (5 blocks). Households were selected by systematic random sampling and proportional to the numbers of households in each cluster.

Data were collected by pharmacy students as trained enumaerators through open questionnaires and direct observation to homes. The inapropriate of drug storage was recorded from the following criteria; drug storage in vulnerably hot or humid locations, in locations that are easily accessible to children, drug storage was mixed with other items at home. Data were coded, checked, and analyzed using SPSS version 23.0. Bivariate logistic regression analysis was applied to detect sociodemographic factors that influence the storage of inappropriate drugs.

This research has obtained ethical approval from the Ethics Committe of Poltekkes Jakarta II. Confidentiality was informed and consent was obtained before data collection.

\section{RESULTS}

Of the 295 respondents, a total of 269 (91.2\%) were women and 219 of them were housewives. An overrepresentation of women in this study was due to inequality in the number of male and female respondents caused by the data collection process carried out on weekdays so that interviews were conducted on housewives. More than half of households store at most 10 items of medicine. The average number of drug items in households that have a toddler is significantly different from the house where there are no toddlers $(p=0.033)$. Likewise with family members who have a history of chronic diseases, the average number of items stored is higher $(\mathrm{p}=0.046)$.

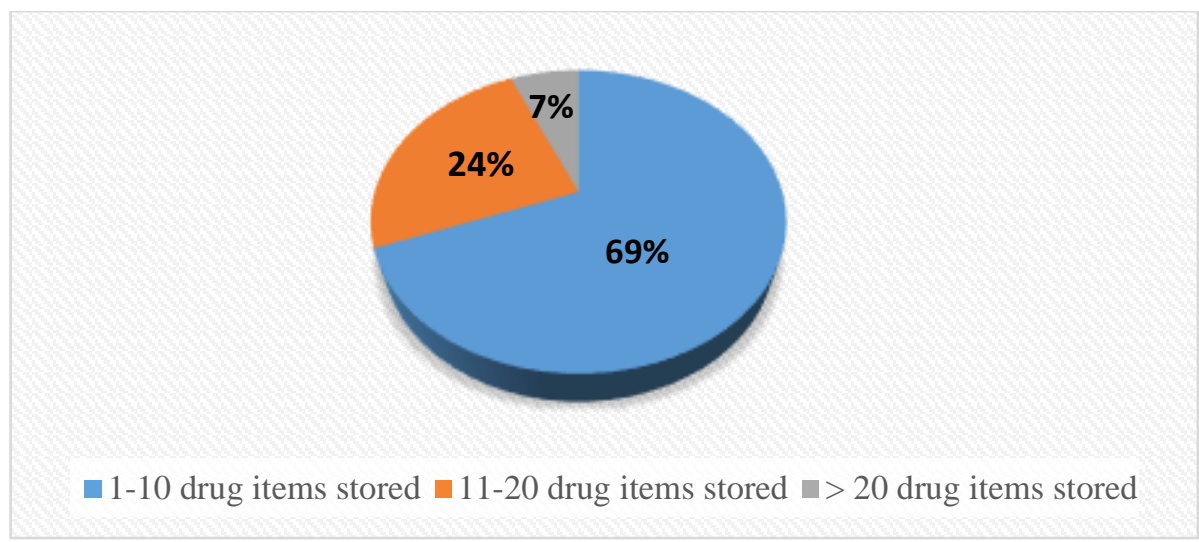

Fig. 1. Household proportion based on number of drug items stored at home

Table 1 illustrates the type drugs and the purpose of storage insampled households. Over 50\% (1422) drug items was OTC drugs, followed by almost 40\% (1019) items ethical drugs, and small number of drugs were remain unrecognizeddue to inadequately labelled.The drugs for future use were the most being stored (1265; $49.2 \%)$. Table 2 shows the six most common drugs kept at home ; analgetic, antipyretic, and NSAIDs (22.6\%), cold and cough preparation $(12.41 \%)$, vitamins (11.40\%), unknown ethical drugs (11.36\%), gastrointestinal agents (10.85\%), and antibiotics (9.96\%). The unknown ethical drugs and antibiotics were the category of stored drugs mostly came from previous prescription.

\begin{tabular}{lcc}
\multicolumn{4}{r}{ Table 1. Drugs kept at home according to the type and purpose } \\
\cline { 2 - 4 } \multicolumn{1}{c}{ Category } & Count & Percent (\%) \\
\cline { 2 - 4 } Type of drugs & 1422 & 55.31 \\
OTC drugs & 1019 & 39.63 \\
Ethical drugs & 130 & 5.06 \\
\hline Unidentified drugs* & 2571 & 100.0 \\
\hline & & \\
\hline The purpose of drugs being stored & 735 & 28.59 \\
In current use & 571 & 22.21 \\
Leftover & 1265 & 49.20 \\
\hline For future use & 2571 & 100.0 \\
\hline
\end{tabular}

*no information regarding the active ingredient and direction of use on primary package 
Table 2. The therapeutic category of drugs kept at home

\begin{tabular}{lcc}
\hline \multicolumn{1}{c}{ Therapeutic Class of drugs } & Count & Percent (\%) \\
\hline Analgetic, antipiretic, NSAIDs & 581 & 22.60 \\
Cold and cough formulations & 319 & 12.41 \\
Vitamins & 293 & 11.40 \\
Unknown ethical drugs $*$ & 292 & 11.36 \\
Gastrointestinal agents & 279 & 10.85 \\
Antibiotics & 256 & 9.96 \\
Cardiovascular agents & 175 & 6.81 \\
Antihistamins & 76 & 2.96 \\
Oral Antidiabetic & 48 & 1.87 \\
Antiseptics & 28 & 1.09 \\
Unidentified drugs $* *$ & 130 & 5.60 \\
\hline
\end{tabular}

*leftover prescription drugs with inadequate label in primary package

** drugs with damaged containers or torn apart

Tabel 3. Demographic characteristics of households associated with inappropriate home-drug storage

\begin{tabular}{|c|c|c|c|c|c|c|}
\hline \multirow[b]{2}{*}{ Characteristics } & \multicolumn{6}{|c|}{ Number of respondents $(n=295)$} \\
\hline & $\begin{array}{l}\text { Count } \\
(\mathrm{n}, \%)\end{array}$ & $\begin{array}{l}\text { Proper } \\
\text { storage } \\
\text { (n) }\end{array}$ & $\begin{array}{l}\text { improper } \\
\text { storage } \\
\text { (n) }\end{array}$ & $\mathrm{P}$ & AOR & $\begin{array}{c}95 \% \\
\text { CI }\end{array}$ \\
\hline \multicolumn{7}{|l|}{$\underline{\text { Gender }}$} \\
\hline Male & $26(8.8)$ & 12 & 14 & 0.164 & 1.112 & $\begin{array}{c}0.457- \\
2.707\end{array}$ \\
\hline Female & $\begin{array}{c}269 \\
(91.2)\end{array}$ & 162 & 107 & & & \\
\hline \multicolumn{7}{|l|}{ Age } \\
\hline$<45$ years old & $\begin{array}{c}162 \\
(54.9)\end{array}$ & 106 & 56 & 0.013 & 0.591 & $\begin{array}{c}0.342- \\
1.021\end{array}$ \\
\hline $\begin{array}{l}45 \text { years old and } \\
\text { above } \\
\text { Level of education }\end{array}$ & $\begin{array}{c}133 \\
(45.1)\end{array}$ & 68 & 65 & & & \\
\hline None & $8(2.7)$ & 3 & 5 & 0.161 & 1.184 & $\begin{array}{c}0.845- \\
1.659\end{array}$ \\
\hline Primary school & $\begin{array}{c}141 \\
(47.8)\end{array}$ & 77 & 64 & & & \\
\hline Secondary school & $\begin{array}{c}124 \\
(42.0)\end{array}$ & 78 & 46 & & & \\
\hline Tertiary & $22(7.5)$ & 16 & 6 & & & \\
\hline \multicolumn{7}{|c|}{ Employement Statues } \\
\hline Employed & $\begin{array}{c}67 \\
(22.7)\end{array}$ & 29 & 38 & 0.003 & 0.418 & $\begin{array}{c}0.229- \\
0.760\end{array}$ \\
\hline Unemployed & $\begin{array}{c}228 \\
(77.3) \\
\end{array}$ & 145 & 83 & & & \\
\hline
\end{tabular}

\section{DISCUSSION}

The behavior of storing drugs at home is an important research topic to study because it represents the level of community knowledge in using over the counter (OTC) and prescription drugs. This study refers to several previous studies to determine the adequate drug storage, type of drugs stored according to therapeutic class and purpose of storing [2-7,9].

According to the therapeutic class of drugs, analgesics was the most type of drugs being kept in household (581; $22.6 \%$ ). This in line with the majority of research results in various parts of the world $[2-4,7,9,10]$. Analgesics as pain relievers have been used widely in communities since this class of drug might available in pharmacy as over the counter 
(OTC) products. Public may purchase analgesics to alleviate minor symptoms before seeking medical attention. However, in this survey, not only OTC analgesics, NSAIDs which required prescription and opioid analgesics (tramadol) were also found in the household. The results of the interview indicated that the respondent obtained it from unauthorized pharmacy. The availability of ethical drugs in unauthorized pharmacy and the free access of prescription drugs in some authorized pharmacies are still become issues that needs to be resolved in Indonesia [9, 11,15]. Lack of control and weak policy enforcement toward access to drugs has triggered improper self-medication behavior.

In addition, antibiotics were also found in the household's drug storage box $(256 ; 9.96 \%)$. Although this result was not as many as in previous study conducted in North Jakarta (anti-infective agents account for $37.1 \%$ drugs stored at home), the presence of antibiotics at home indicates drug storage discrepancies. According to the respondent's statement, some antibiotics were the remnants of previous infection therapy, some were purchased without prescription at authorized pharmacies and drug sellers for treatment in the future. Self-medication using antibiotics is contributed to the risk of increasing bacterial resistance [12,13]. The effort for controling antibiotic resistance has been carried out globally by WHO and the Indonesian government [11,12]. The government formulates general guidelines for antibiotic use to supporta wise antibiotic prescription. In the community, the government reaches out to the public through the Gema Cermat campaign to educate people about the prohibition of using antibiotics on influenza caused by viruses [13,14].

Apart from the issue of ethical drugs purchased without a prescription, in the household there were also unidentified drugs $(309 ; 12.02 \%)$ as no information about active ingredient and direction for use in the primary packaging. Since there were no expiration date in the packaging, these inadequately labeled products may expose users to potentially harmful effects of the drugs.

According to the purpose of drugs being stored, almost $50 \%$ of drugs in household cabinets are intended for future use $(1265 ; 49.2 \%)$. This is an agreement with other studies done in Uganda and Sudan $[3,16]$. Drug storage for future needs may be influenced by the persuasive advirtisement of over the counter products. Approximately $22 \%$ of drugs kept at home were leftover drugs. The presence of leftover drugs at home indicates a number of causes, including non-adherence to medication due to forgetfulness or occurrence of side effects, large quantities for pro-renata drugs, and therapeutic regimens that have changed from prescriber $[3,17]$. Some respondents did not know how to dispose of leftover drugs and claimed they were not well informed about this from healthcare professionals. Some of them claim to dispose of the drugs at general waste disposal. Improper disposal of pharmaceutical products can pollute the environment. Studies reported, starting from the active substances, expients and drug packaging may damage ground water used to meet daily needs $[18,19,20]$.

In term of improper drug storage, this study found that significant number of households stored the drugs in humid cupboard, above the refrigerator, within reach of children and mixed with other goods at home. Similar to this finding, a research conducted in Qatar described the poor management in which most of respondents had no designated compartment for storing medicines at home. This potentially increase the risk of accidental ingetion in children under 5 years olds [22,23] Furthermore, improper storage may influence the physicochemical properties of the drugs [24, 25]. Storage conditions above $30^{\circ} \mathrm{C}$ and high humidity may accelerate drug degradation, reduce dissolution and affect drug bioaviability in the body. For example, acetosal which can be degraded to acetic acid and salicylic acid causing gastric irritation [26].

The logistic regression analyses in this study described that older age (45 years and above) was associated with inadequate drug storage $(\mathrm{p}=0.05)$. In addition, the average numbers of drugs being stored was corelated with chronic disease treatments in household $(\mathrm{p}=0.046)$. It is assumed that the older respondents may get multiple prescription due to their chronic diseases and experienced dificullty in administrating medicines daily. They may also tend to place the prescribed drugs in many storage locations to be easily accessed.

The analyses showed that employment status also negatively affect the home medicine storage (0.04). People with tight working schedule may not pay attention about how to properly store the medicines at home. This finding in accordance with some studies portrayed the housewives are more responsible for managing medicines stored for all members of family $[3,6,10]$.

This study may have limitation for not including the household economic status as a predictor for improper drug storage as well as the accessibility of healthcare facilities. Although may not represent wide population,all of these findings raise concerns about the important of healthcare provider role especially pharmacist for actively promoting the proper home drug storage and educating people about rational use of drugs being stored.

\section{REFERENCES}

1. J. Okumura, S. Wakai,T. Umenai, Drug Utilization and self-medication in rural communities in Vietnam, Soc Sci Med 54, 1875-1886 (2002)

2. L..De Bolle, E.Mehuys, E.Adriaens, J.P. Remon, L.Van Bortel, T. Christiaens, Home medication cabinets and self-medication : a source of potensial health threats? Ann Pharmacother. 42, 572-9 (2008)

3. M. Ocan, G. Bbosa, P. Waako, J. Oqwal-Okeng, C. Obua, Factors predicting home storage of medicines in Northern Uganda. BMC Public Health. 14, 650 (2014)

4. A. Jassim, In-home Drug Storage and Self-medication with Antimicrobial Drugs in Basrah, Iraq, OMJ 25, 79-87 (2010) 
5. N. Kheir, M.S. El Hajj, K.Wilbur, R.M.L. Kaissi, A. Yousif, An Exploratory study on medications in Qatar homes, Drug Healthc Patient Saf. 3, 99-106 (2011)

6. I. Tsiligianni, C. Delgatty, A. Alegakis, C. Lionis, A household survey on the extent of home medication storage. A cross-sectional study from rural Crete, Greece, The European Journal of General Practice, 18, 3-8 (2012)

7. S.L. Gracia-Vásquez, E. Ramírez-Lara, I.A. Camacho-Mora, L.G. Cantú-Cárdenas, Y.A Gracia-Vásquez, P.C. Esquivel-Ferriño, M.A. Ramírez-Cabrera, P. Gonzalez-Barranco, An analysis of unused and expired medications in Mexican households. Int J Clin Pharm. 37, 121-6 (2015)

8. Indonesian Ministry of Health.Basic Health Research (RISKESDAS)(2013)

9. R. Gitawati, Pattern of Household Drug Storage. Jurnal Kesehatan Masyarakat Nasional, 9, 27-31 (2014)

10. A. Wondimu, F. Molla, B. Demeke, T. Eticha, A. Assen, S. Abrha, W. Melkam, Household Storage of Medicines and Associated Factors in Tigray Region, Northern Ethiopia, PLoS One, 10, 1-9 (2015)

11. H.Parathon, K. Kuntaman, T.H. Widiastoety, B.T. Muliawan, A. Kurniawati, M.Qibtiyah, Z. Djanun, J.F. Tawilah, T.Aditama, V. Thamlikitkul, S.Vong, Progress towards antimicrobial resistance containment and control in Indonesia, BMJ, 358: j3808 (2017)

12. World Health Organization (WHO), Global Action paln on Antimicrobial Resistance(2015)

13. Peraturan Menteri Kesehatan Republik Indonesia no.2406/Menkes/XII/2011 tentang Pedoman umum penggunaan antibiotik (2011)

14. Sosialisasi Gema Cermat Tahun 2017 di 81 Kabupaten/Kota, [accessed 21 Agustus 2018] available fromhttp://farmalkes.kemkes.go.id/2017/09/sosialisasi-gema-cermat-tahun-2017-81kabupatenkota/\#.W4EF6egzbIU

15. M.Amelia, Polda Metro Bongkar Peredaran Obat Keras di Apotek di Tangerang [accessed 23 Agustus 2018] available from : https://news.detik.com/berita/d-3394688/polda-metro-bongkar-peredaran-obat-keras-di-apotek-di-tangerang

16. M.A. Yousif, In-home storage and utilization habits : a Sudanese study, East Mediterr Health J, 8, 422-431, (2002)

17. R. Braund, B.M. Peake, L. Shieffelbien, Disposal Practices for unused medications in New Zealand, Environ Int., 35, 952-955, (2009)

18. J. Corcoran, M.J. Winter, C.R. Tyler, Pharmaceutical in the aquatic environment : a critical review of the evidence for health effects in fish. Crit Rev Toxicol, 40, 287-304, (2010)

19. T.J. Runnalls, L. Margiotta-Casaluci, S. Kugathas, P. Sumpter, Pharmaceuticals in the aquatic environment : steriods and antisteriods as high priorities for research. Hum Ecol Risk Assess, 16, 1318-38, (2010)

20. S.M.Wieczorkiewicz, Z. Kassamali, L.H. Danziger, Behind the closed doors : medication storage and disposal in the home, Ann Pharmacother, 47, 482-489, (2013)

21. K. Cameron, Medication safety in the home : the need for pharmacist involvement. Can Pharm J, 140, 47-49, (2007)

22. N. Kheir, M.S. El Hajj, K. Wilbur, R.M.L Kaissi, A. Yousif, An exploratory study on medications in Qatar homes, Drug Healthc Patient Saf, 3, 99-106 (2011)

23. R. Ozdemir, B. Bayrakci, O. Tekşam, B. Yalçin, G. Kale, Thirty-three-year experience on childhood poisoning, Turk J Pediatr, 54, 251-259, (2012)

24. G.W. Frimpter, A.E. Timpanelli, W.J. Eisenmenger, H.S. Stein, L.I. Ehrlich, Reversible 'Fanconi Syndrome' caused by degraded tetracycline, JAMA, 184, 111-113, (1963)

25. B. Stanisz, K. Regulska, Kinetics of degradation of imidapril hydrochloride in finished dosage formulations, Acta Pol Pharm, 70, 737-742, (2013)

26. A.Y. Tong, B.M. Peake, R. Braund, Disposal practices for unused medications around the world. Environment International 37, 292-298, (2011) 